\title{
HAZARDOUS EFFECTS OF ARSINE: A SHORT REVIEW
}

\section{DARIA PAKULSKA and SŁAWOMIR CZERCZAK}

Department of Scientific Information

Nofer Institute of Occupational Medicine

Łódź, Poland

\begin{abstract}
This review details the known health effects of arsine as well as the existing theories on the mechanism by which arsine exerts its toxic effect and conditions of occupational exposure to this gas. Exposure to arsine in occupational settings occurs mostly in the chemical and metallurgical industries when nascent hydrogen reacts with metallic arsenic or arsenic compounds. The available data indicate that in these branches of industry arsine is often a cause of unexpected serious poisoning. The gas affects primarily blood and kidneys. Acute arsine poisoning is known to result in massive damage to red blood cells through the oxidative mechanism, probably by the formation of hydrogen peroxide and adducts with oxyhemoglobin. According to another hypothesis, arsine acts on sodium-potassium pomp mechanism, producing subsequent red blood cell swelling and hemolysis. Rapid hemolysis may lead to oliguric renal failure and death. Symptoms of chronic poisoning are similar to those observed in acute poisoning. The main difference is a longer latency period. Late effects of chronic exposure to low levels of arsine have not yet been precisely identified.
\end{abstract}

Key words:

Arsine, Health effects, Occupational exposure

\section{INTRODUCTION}

Arsine $\left(\mathrm{AsH}_{3}\right)$ (CAS No 7784-42-1) does not occur in the natural environment. It is produced by man (intentionally or accidentally) or by microorganisms.

Arsine was first obtained by Scheele in 1775. It is now produced commercially either by the reaction between aluminum arsenide and water or hydrochloric acid, or by the electrochemical reduction of arsenic compounds in acid solution [1]. $\mathrm{AsH}_{3}$ is highly poisonous, nonirritating, and colorless with a mild garlic-like odor, which is not specific as it is characteristic of the majority of arsenical compounds. The absolute threshold for detection of arsine odor by smell is $3 \mathrm{mg} / \mathrm{m}^{3}$ [2]. Since arsine exhibits toxicity at concentrations far below those at which its smell is detectable, there is no odor warning if toxic concentrations occur.

This gas is extensively used in the semiconductor industry and manufacture of light emitting diodes. During World
War II, arsine was studied as a chemical warfare agent, but never used on the battlefield.

Little attention has been given to arsine despite its extensive use and the risk of its unintended formation during many chemical and metallurgical processes, and there is no specific study of its mutagenicity and carcinogenicity.

\section{SOURCES OF EXPOSURE}

The presence of arsine in workplaces occurs mostly due to its accidental formation as a by-product during industrial processes, particularly in the chemical and metallurgical industries, and arsine itself is used to a lesser extent mainly in the semiconductor industry as a doping agent.

In nature, exposure to arsine can occur as a result of the fungi-induced biotransformation of arsenic compounds, such as arsenites and arsenates.

Received: December 12, 2005. Accepted: February 1, 2006.

Address reprint requests to D. Pakulska, PhD, Department of Scientific Information, Nofer Institute of Occupational Medicine, Teresy 8, 91-348 Łódź, Poland (e-mail: pakdar@imp.lodz.pl). 
It is reported that arsine poisoning occurs most frequently during smelting and refining of metals, but also during galvanization and burnishing, blackening of zinc/aluminum, etching, plating, and other operations.

Arsine gas is emitted whenever nascent (freshly formed) hydrogen is generated in the presence of arsenic, or when water reacts with a metallic arsenide. Most cases of industrial poisoning with arsine have been associated with the use of acids and crude metals, which contained arsenic in a form of impurity. The action of water, air moisture and rain water on hot metallic dross contaminated with arsenic may lead to arsine formation. The gas can also be produced by the hydrolysis of arsenides with acid or water. Arsenic impurities contained in coal may be transformed to arsine during the processes of coal conversion to gas.

Table 1. Examples derived from the literature showing possible scenarios of human exposure to arsine [3]

\begin{tabular}{|c|c|c|}
\hline Place of exposure & Scenarios of exposure & References \\
\hline $\begin{array}{l}\text { Chemical plant, where } \\
\text { herbicide was produced } \\
\text { by reaction of methyl chloride } \\
\text { with sodium arsenite }\end{array}$ & $\begin{array}{l}\text { An aluminum ladder was by mistake substituted for the usually used wooden ladder to place into } \\
\text { the tank containing aqueous sodium arsenite. The aluminum ladder caused evolution of nascent } \\
\text { hydrogen. The three ingredients necessary for the evolution of arsine gas were present in the tank: } \\
\text { arsenic, nascent hydrogen, and aluminum. } \\
\text { The workers saw "bubbling" at the foot of the ladder. }\end{array}$ & {$[4]$} \\
\hline $\begin{array}{l}\text { Copper smelting and } \\
\text { refinery }\end{array}$ & $\begin{array}{l}\text { A galvanized bucket was accidentally used instead of a plastic one to transfer a sulphuric acid solution } \\
\text { containing both arsenic and antimony. Arsine was released when sulfuric acid solution got in touch } \\
\text { with galvanized pail. }\end{array}$ & [5] \\
\hline Bronzing process & $\begin{array}{l}\text { During the technological process of bronze plating, the alloy containing zinc was by mistake placed } \\
\text { into the bronzing solution (instead of brass), which contained arsenic and ferric chlorides in the } \\
\text { concentrated hydrochloric acid. } \\
\text { The presence of zinc in this solution caused formation of arsine. }\end{array}$ & {$[6]$} \\
\hline $\begin{array}{l}\text { Transmission repair } \\
\text { shop }\end{array}$ & $\begin{array}{l}\text { Aluminum transmission casings of trucks used for arsenical herbicide application were cleaned in a } \\
\text { hot acidic detergent bath. Since some remains of the pesticides were deposited on the casings, their } \\
\text { contact with the acidic detergent caused rapid evolution of arsine gas. }\end{array}$ & [7] \\
\hline Artist workshop & $\begin{array}{l}\text { Artists working on the restoration of a famous painting were arsine poisoned. Arsine was generated } \\
\text { as a result of the reaction between nascent hydrogen and small amount of arsenic contained in surface } \\
\text { material of painting. }\end{array}$ & [8] \\
\hline Ferrous metal foundry & Arsine was released when hot dross, containing arsenical impurity, was coated with water. & [9] \\
\hline Burnishing of metals & $\begin{array}{l}\text { Small zinc-tin alloy components were treated with solution containing hydrochloric acid and arsenous } \\
\text { anhydride. Arsenic was reduced to arsine in the presence of nascent hydrogen in an acid environment. }\end{array}$ & {$[10]$} \\
\hline $\begin{array}{l}\text { Blackening of zinc/aluminum } \\
\text { alloy parts }\end{array}$ & Arsine was generated during treatment of zinc/aluminum alloy with acid solution. & [11] \\
\hline $\begin{array}{l}\text { Soil contained } \\
\text { arsenic compounds }\end{array}$ & $\begin{array}{l}\text { Arsine was generated from arsenic compounds present in soil as a result of its biotransformation } \\
\text { induced by fungi or bacteria (Alcaligenes and Pseudomonas). The authors concluded that the reduction } \\
\text { of arsenic compounds to arsine is the primary mechanism for gaseous loss of arsenicals from solid. }\end{array}$ & [12] \\
\hline Transistor industry & Arsine leaking during its delivery to a semiconductor division. & [13] \\
\hline $\begin{array}{l}\text { Microelectronic } \\
\text { industry }\end{array}$ & Arsine may be released during its manufacture of semiconductor and its storage. & [14] \\
\hline $\begin{array}{l}\text { Microelectronic } \\
\text { industry }\end{array}$ & Arsine is formed during reaction of gallium arsenide with concentrated acid. & {$[15,16,17]$} \\
\hline Lead acid battery industry & Arsine may be generated by the reaction of battery acid with lead-arsenic alloy. & [18] \\
\hline Damp houses & $\begin{array}{l}\text { When wallpapers decorated with green arsenical pigments are used in damp houses, moulds growing } \\
\text { on the paper cause the formation of compounds including trimethylarsine, and possibly arsine itself. }\end{array}$ & [19] \\
\hline $\begin{array}{l}\text { Home circumstances, cot } \\
\text { mattresses }\end{array}$ & $\begin{array}{l}\text { Arsine was generated from polyvinyl chloride covered cot mattresses. It was suggested that fungus } \\
\text { Scopulariopsis brevicauli caused conversion of } 10,10 \text { 'xybisphenoxyarsine (used as a preservative) to } \\
\text { arsine gas. }\end{array}$ & {$[20,21]$} \\
\hline $\begin{array}{l}\text { Home circumstances, cot } \\
\text { mattresses }\end{array}$ & $\begin{array}{l}\text { At least } 50 \% \text { of all cot deaths in New Zealand occur when babies are sleeping on sheepskins. } \\
\text { Trimethylarsine and possibly arsine itself are generated by fungal action on arsenic compounds } \\
\text { contained in sheepskins and other cot mattresses. }\end{array}$ & {$[22]$} \\
\hline
\end{tabular}


Gas intoxications are frequently unexpected since very small amounts of arsenic impurity can result in a dangerous emission of arsine (Table 1).

\section{HEALTH EFFECTS}

The first case of arsine poisoning was reported in 1815, when Scheele, a German chemist, inhaled a small amount of arsine gas in his laboratory. He died 9 days later [3].

\section{Acute poisoning}

Arsine is the most toxic form of arsenic. Inhalation of 800 $\mathrm{mg} / \mathrm{m}^{3}(250 \mathrm{ppm})$ of arsine causes instant death; exposure to $80-160 \mathrm{mg} / \mathrm{m}^{3}(25-50 \mathrm{ppm})$ is lethal after $30 \mathrm{~min}$; and to $32 \mathrm{mg} / \mathrm{m}^{3}(10 \mathrm{ppm})$ is lethal after a longer period of time [14]. Symptoms of arsine poisoning may occur within 1 to $24 \mathrm{~h}$ after exposure, depending on the concentration and time of exposure [23]. Exposure to $9.72-32.4 \mathrm{mg} / \mathrm{m}^{3}$ ( 3 to $10 \mathrm{ppm}$ ) may induce symptoms within a few hours, the concentration of 32.4 to $194.4 \mathrm{mg} / \mathrm{m}^{3}$ (10 to $60 \mathrm{ppm}$ ) may exert a hazardous effect within 30 to $60 \mathrm{~min}$, and of $810 \mathrm{mg} / \mathrm{m}^{3}(250 \mathrm{ppm})$ is immediately fatal [24].

Since arsine does not cause irritation, the affected person may fail to experience discomfort at the time of exposure [23]. First symptoms, which may appear after the latency period include: headache, balance disorders, chills, dyspnea, nausea, vomiting, diarrhea, and pain in the chest, lumbar area and upper abdomen. Physical examination often reveals fever, tachycardia and increased breath rate. Moreover, enlargement and tenderness of the liver and spleen as well as tenderness of the costovertebral angle occur. Within a few hours after exposure, discoloration of urine up to a port wine hue [25] and unusual slate-bronze skin color may be observed [26]. Jaundice is seen within 24-48 h after exposure. Vertical white lines on the nails (Mee's lines) can be observed 2-3 weeks following the exposure.

Arsine acts predominantly as a hemolytic agent. Laboratory diagnostics show hemolytic anemia with intensity depending on the concentration and time of exposure. Blood testing indicates the increased white blood cells count, elevated iron and free hemoglobin, increased erythrocytes count with basophilic and Heinz bodies, basophilic stippling, anisocytosis, poikilocytosis, red blood cell fragments and ghost cells, which demonstrates the ongoing damage to erythrocytes [23]. Toxic granules may be observed in leukocytes. Methemoglobin may also be present in blood, but its concentration is usually not high [27]. Urinalysis shows free hemoglobin, hemosiderin, erythrocytes, proteins and casts, indicating hemoglobinuria and proteinuria. Methemoglobin can also be present in urine. Urine arsenic concentration higher than $200 \mu \mathrm{g} / \mathrm{l}$ reveals the absorption of a toxic dose. The renal blood flow is usually reduced. The impairment of renal function is correlated with the degree of intravascular hemolysis. Urine production decreases as hemolysis progresses [23]. Renal tubules obturation, oliguria or even anuria may also occur. Persistent morphological and functional changes in the renal tissue of arsinepoisoned workers most often leads to death [28].

No antidotes to arsine are available. In acute renal failure only exchange transfusions may remove arsine and prevent continuing failure [28].

The levels of bilirubin and lactate dehydrogenase in serum are elevated, however, severe damage to the liver is rarely found $[29,30]$. Acute jaundice and tenderness of the liver may appear after $24 \mathrm{~h}$ since the acute arsine poisoning.

Toxic pulmonary edema or acute circulatory failure has also been reported as the cause of death in patients with arsine poisoning [30].

Electrocardiographic (ECG) abnormalities, T wave elevation tachycardia, have also been noted. ECG may indicate hyperkaliemia traits. The ECG changes may last for several months. Acute myocardial failure may also occur.

Abnormalities in the nervous system (both central and peripheral) may frequently occur [23]. Similarities between the nervous system symptoms in arsine and arsenic poisoning indicate that arsine polyneuropathy may be due to the arsenic activity. There are reports on disorientation, hallucination [26] and mild psycho-organic syndromes in arsine-poisoned individuals. Gosselin et al. [26] described polyneural inflammation of the upper and lower extremities 3 months after the end of exposure. Toxic polyneuropathy and mild psycho-organic syndromes were related to the exposure time. Encephalopathy reported in occu- 
pational poisoning with arsine was manifested by anxiety, excitement and disorientation several days after the exposure. The cardiac, pulmonary, hepatic and neurological changes are considered to be secondary to the severe hemolytic anemia and renal failure. Changes in many body organs are most probably due to the deposition of erythrocyte debris in capillaries.

The effects of acute arsine poisoning observed in animals are consistent with those observed in humans and attributed chiefly to the hemolytic effect of the chemical. The symptoms of acute arsine poisoning include sleepiness, weak breath, lack of appetite, vomiting, diarrhea, hemoglobinuria, jaundice, paralysis, and death after several days since exposure. Histopathological examinations of animals under acute exposure to $16.2 \mathrm{mg} / \mathrm{m}^{3}$ (5 ppm) showed the increased hemosiderosis and extramedullary hemopoietic activity in the spleen as well as cholestasis in the liver [31,32].

\section{Chronic poisoning}

Arsine in very small concentrations may cause cumulative, damaging effects. The symptoms of chronic poisoning in humans are similar to those observed in acute poisoning. The main difference between chronic and acute poisoning is a longer period of latency. The symptoms of chronic arsine poisoning in humans comprise intense focal headache, nausea, low-grade fever, paresthesia, hemolysis, anemia, hepatic and renal impairments, and characteristic fingernail changes (Mee's lines) [7]. A decrease in hemoglobin concentration and the presence of basophilic granulocytes in red blood cells are observed. Bulmar et al. [33] found that the degree of anemia was proportional to the duration of arsine exposure.

The symptoms of subacute and subchronic arsine poisoning in animals mainly concern blood and are manifested by hemolysis, decrease in erythrocyte count and hemoglobin concentration. Blood changes were observed in mice exposed to arsine for $5,15,90$ days at $8.1 \mathrm{mg} / \mathrm{m}^{3}(2.5 \mathrm{ppm})$. An increase in absolute reticulocyte counts (after 15 and 90 days of exposure) as well as in blood concentration of methemoglobin (after 90 days of exposure) were observed in animals exposed to $8.1 \mathrm{mg} / \mathrm{m}^{3}(2.5 \mathrm{ppm})$ [31]. A signifi- cant decrease in red blood cells was observed in mice exposed to arsine at concentrations of 8.1 and $16.2 \mathrm{mg} / \mathrm{m}^{3}$ ( 2.5 and $5 \mathrm{ppm})$ for 14 days $(6 \mathrm{~h} /$ day). Similar changes in hematological parameters were observed in the group of mice exposed to arsine for 12 weeks [34].

\section{Carcinogenicity and mutagenicity}

No reports on specific studies of carcinogenicity and mutagenicity of arsine are available.

\section{Reproductive toxicity}

The results of animal experiments have not revealed developmental toxicity of arsine. Mice and rats were exposed to arsine by inhalation at $0.08,1.6$ and $8.1 \mathrm{mg} / \mathrm{m}^{3}(0.025$, $0.5,2.5 \mathrm{ppm}$ ) between the 6th and 15th day of gestation. The number of live fetuses, mean fetal body weight as well as the percentage of resorptions and malformations per litter did not differ from the findings in controls. However, significant splenomegaly was observed in maternal individuals of mice and rats exposed to $8.1 \mathrm{mg} / \mathrm{m}^{3}$ (2.5 ppm) [35].

\section{Mechanism of toxicity}

After being absorbed by the lungs, arsine enters red blood cells, induces hemolysis and impairs oxygen transport by conversion of $\mathrm{Fe}$ (II) to $\mathrm{Fe}$ (III).

Some authors postulate an oxidative mechanism of toxicity [31,32,36,37], while others suggest a mechanism dependent on the reaction with sulfhydryl groups [38], both of which are most probably responsible for the toxicity of arsine.

\section{Oxidative mechanism of toxicity}

Hatlelid and Carter [37] postulated that the hemolytic activity of arsine is related to oxidative stress, most probably through the formation of hydrogen peroxide and arsine adducts with oxyhemoglobin, according to the following formulas:

$$
\begin{gathered}
\mathrm{H}_{2} \mathrm{As}-\mathrm{H}+\mathrm{HbO}_{2}=\mathrm{H}_{2} \mathrm{As}+\mathrm{Hb}-\mathrm{O}_{2}-\mathrm{H} \\
\mathrm{H}_{2} \mathrm{As}+\mathrm{Hb}-\mathrm{O}_{2}-\mathrm{H}=\text { adduct }+\mathrm{H}_{2} \mathrm{O}_{2} .
\end{gathered}
$$

When the antioxidant system of enzymes and cofactors in red blood cells is overwhelmed, reactive oxygen spe- 
cies (ROS) generate damage to oxyhemoglobin, leading to rapid denaturation and precipitation of proteins [37]. Aggregation of precipitated molecules and their binding to the inner surface of red blood cells (Heinz bodies) lead to a redistribution of membrane proteins and increased membrane rigidity [39].

Oxidation of heme iron induces the formation of hemin, which results in the oxidation of membrane protein sulfhydryl groups, dissociation of membrane skeletal protein and perturbation of membrane ion gradients [39]. Ultimately, the Heinz bodies and hemins increase the fragility of red blood cells membrane and predispose the cells to fragmentation, so that, the degradation of hemoglobin may lead to hemolysis.

Some studies suggest that the sulfhydryl groups of glutathione prevent hemoglobin oxidation, becoming essential for the maintenance of the intact erythrocyte structure [31].

In the in vitro studies, a decrease in reduced glutathione concentration in human red blood cells is found to correlate with the hemolytic action of arsine. Blair et al. [31] recorded a $60 \%$ decrease in reduced glutathione level in erythrocytes exposed to arsine in vitro. However, later investigations of Hatlelid et al. [36] contradicted these findings. In these studies, the depletion of reduced glutathione in dog red blood cells neither preceded nor coincided with hemolysis.

\section{Mechanism dependent on the reaction with sulfhydryl groups}

According to the hypothesis of sulfhydryl-dependent mechanism of arsine toxicity [40], arsine reacts with the sulfhydryl group of $\mathrm{Na}^{+} \mathrm{K}^{+}$-ATPase causing impairment in the sodium-potassium pump mechanism with subsequent red blood cell swelling and hemolysis. The affinity of trivalent arsenic (As(III)) for the sulfhydryl group is well known. Winski et al. [38] observed immediate profound abnormalities in membrane ultrastructure and in red blood cells volume, which were manifested by potassium leakage, sodium influx and increases in hematocrit in red blood cells exposed to arsine. At the same time, ATP levels did not significantly decrease and ATP-ase was not inhibited by arsine. However, dog erythrocytes without $\mathrm{Na}^{+} \mathrm{K}^{+}$-ATP-ase, hemolysed when exposed to arsine, which may suggest that $\mathrm{Na}^{+} \mathrm{K}^{+}$-ATP-ase is only partially responsible for red blood cell damage [36,38]. Levinsky et al. [40] suggested that hemolysis in arsine-exposed red blood cells depended on membrane disruption caused by arsine-hemoglobin metabolites, which are the ultimate toxic species.

Although it is generally held that the kidney and other organs failure is due to the effects of red blood cell debris slugging within the microcirculation, arsine has also been demonstrated to have a direct toxic effect on kidney glomeruli and tubules [41].

\section{Toxicokinetics}

In humans and animals, arsine is easily absorbed via the lungs and mucous surface of the respiratory tract and dissolved in body fluids. It is degraded metabolically to trivalent arsenic (As(III)) as well as to pentavalent arsenic $(\mathrm{As}(\mathrm{V}))$. As(III) is methylated to monomethylarsonate(V) and dimethylarsinate $(\mathrm{V})$ [3]. It is plausible that the conversion of $\mathrm{As}(\mathrm{III})$ to $\mathrm{As}(\mathrm{V})$ and As methylation is a detoxification process since the arsenic species have a lower affinity for tissues than As(III) [1].

After exposure, blood concentration of arsine increases rapidly, whereas its distribution to the liver, kidneys and other organs is much slower. After two weeks, arsenic is stored in the hair, skin and bones.

Organ analyses for arsenic in arsine poisoned people indicate that the highest arsenic concentrations occur in the liver, but its high amounts are also found in lungs and kidneys. No arsenic was detected in the gastric contents.

Rats (both males and females) exposed to arsine at concentrations of $0.08,1.62$, and $8.1 \mathrm{mg} / \mathrm{m}^{3}$ for 90 days displayed an increased level of arsenic in the liver, which was correlated with the increased arsine concentration in the air. Arsenic concentration in the liver of rats exposed to arsine at $8.1 \mathrm{mg} / \mathrm{m}^{3}$ was approximately five times higher than in controls [32].

Arsine is mainly excreted with urine. The highest urinary excretion occurs within the first 5 days after exposure to arsine. The clearance of urinary excretion equals to $7.8 \mathrm{ml} / \mathrm{h} / \mathrm{kg}$ and the rate of removal through other routes is $5.27 \mathrm{ml} / \mathrm{h} / \mathrm{kg}$ [42]. 
In a driver exposed to arsine for 1-2 min, the level of total arsenic in urine amounted to $720 \mu \mathrm{g} / \mathrm{l}$ on the day of poisoning and decreased to $10 \mu \mathrm{g} / \mathrm{l}$ on the fourth day after exposure [13].

Arsenic concentration in urine of two employees exposed to arsine during drain cleaning was 0.85 and $0.97 \mathrm{mg} / \mathrm{kg}$, whereas in persons working near the drain, urine concentration of arsenic was found to be 0.30 and $0.12 \mathrm{mg} / \mathrm{kg}$ [43]. The arsenic concentration in acute-poisoned people amounted to $3940 \mu \mathrm{g} / \mathrm{l}[10]$.

\section{BIOLOGICAL MONITORING}

Arsenic concentration in urine, blood, hair, and nails can be used for biological monitoring of arsenic exposure. The measures, however, are not specific for arsine [44].

Urine is the preferred specimen, as renal excretion is the major route of elimination of inorganic arsenic and its metabolites from the human body. Apostoli et al. [42] found the following arsenous compounds in urine of acutely arsine-poisoned subjects: monomethylarsonate(V), dimethylarsinate(V), As(III), markedly lower excretion of arsenobetaine, and $\mathrm{As}(\mathrm{V})$.

The normal level of arsenic in urine is less than $0.01 \mathrm{mg} / \mathrm{l}$ $(10 \mu \mathrm{g} / \mathrm{l})$ [45]. Landrigan et al. [46] observed strong relationship between urinary arsenic concentration and arsine exposure level among workers of a lead-acid battery manufacturing factory. It was estimated that total arsenic concentrations in urine in excess of $50 \mu \mathrm{g} / \mathrm{l}(0.67 \mu \mathrm{mol} / \mathrm{l})$ corresponded with arsine concentrations in the air above $15.6 \mu \mathrm{g} / \mathrm{m}^{3}$.

In Poland, the Intersectoral Committee for MAC and MAI Values recommends the value of $35 \mu \mathrm{g} / \mathrm{l}$ as biological exposure index (BEI) for the sum of inorganic arsenic and its methylated metabolites in urine [45]. The same value of $35 \mu \mathrm{g} / \mathrm{l}$ as the sum of arsenic metabolites in urine, most likely observed at $0.01 \mathrm{mg} / \mathrm{m}^{3}$, based on the estimated risk for lung cancer, is recommended as BEI by the American Conference of Governmental Industrial Hygienists (ACGIH). However, ACGIH does not apply this value to exposure to arsine, which is an acute toxicant [47].
Blood arsenic concentration is a less sensitive indicator of exposure to arsine. Since the majority of arsenic compounds in human blood disappear rapidly, blood arsenic content reflects exposure to arsine only for a short time [10].

The trivalent form of arsenic accumulates in hair, pubes and nails, as a result of its binding to the thiol group of scleroprotein keratin, therefore arsenic content may be used for monitoring of both short- and long-term exposures in contrast to urine arsenic content, which reflects short-term exposures only. Increased concentrations of arsenic in hair, pubes, finger- and toe-nails were found in workers exposed to arsine at the bronzing of brass products, where the arsine level in the breathing zone was $0.08 \mathrm{mg} / \mathrm{m}^{3}$ for sampling time of $35-40 \mathrm{~min}$ [6]. Arsenic contents were $10.8-76.1 \mathrm{mg} / \mathrm{kg}$ in hair, $8.6-63.1 \mathrm{mg} / \mathrm{kg}$ in pubic hair, $15-188 \mathrm{mg} / \mathrm{kg}$ in finger-nails, and $37.1-60.9 \mathrm{mg} / \mathrm{kg}$ in toe-nails. In individuals employed in other departments, arsenic concentrations were lower $(3.33-16 \mathrm{mg} / \mathrm{kg}$, $5.61-38.5 \mathrm{mg} / \mathrm{kg}, 9.03-53.3 \mathrm{mg} / \mathrm{kg}$, and $1.06-5.79 \mathrm{mg} / \mathrm{kg}$, respectively. In adults not exposed to arsenic at work, concentrations of arsenic in hair are usually lower than $1 \mathrm{mg} / \mathrm{kg}$, and lower than $3 \mathrm{mg} / \mathrm{kg}$ in nails [48].

The BEI Committee of ACGIH does not recommend measurements of arsenic in hair and nails because of the lack of suitable database, large interindividual variability, and potential contamination of hair and nail samples.

\section{Occupational exposure limits}

Occupational exposure limits are shown in Table 2. In the majority of countries, the values were derived taking account of only arsine-related hemolysis, which is a non-cancer endpoint.

In Germany, due to the inadequate database, especially the lack of data on genotoxicity and carcinogenicity, the compound is listed in Section IIb of the List of MAK (Maximum concentrations at the workplace) and BAT (Biological tolerance values) Values that refers to substances for which no MAK value can be established at present [49]. NIOSH has classified arsine as potential occupational carcinogen. 
Table 2. Occupational exposure limits for arsine in different countries [49,50,51]

\begin{tabular}{lcc}
\hline & Country & \multicolumn{2}{c}{$\begin{array}{c}\text { Concentration } \\
\left(\mathrm{mg} / \mathrm{m}^{3}\right)\end{array}$} \\
\cline { 2 - 3 } & \multicolumn{1}{c}{ TWA } & STEL \\
\hline France & 0.2 & 0.8 \\
United Kingdom & 0.16 & - \\
Germany & Substance for which no MAK value can be established at present \\
Poland & 0.2 & 0.6 \\
USA: & & - \\
ACGIH & $0.16 ;$ NIC: $0.01, \mathrm{~A} 4$ & - \\
OSHA & 0.2 & $0.002 / 15$ min; carcinogen \\
NIOSH & - &
\end{tabular}

TWA - Time-weighted average; STEL - Short-term exposure; ACGIH - American Conference of Governmental Industrial Hygienists;

A4 - Not classifiable as a human carcinogen: Agents which cause concern that they could be carcinogenic for humans, but which cannot be assessed conclusively because of lack of data

\section{CONCLUSIONS}

Arsine is a highly toxic gas that acts predominantly as a hemolytic agent causing hemoglobinuria, jaundice and hemolytic anemia. In the absence of proper therapy, hemolysis may progress to oliguric renal failure and death. The toxicity of the gas brings about the increased osmotic fragility of red blood cells, formation of erythrocyte debris in capillaries and effects on hemopoietic tissue. The current occupational exposure limits in the majority of countries prevent the hemolytic effects of the gas. The data on health effects of long-term exposure to low levels of arsine, including possible mutagenicity, carcinogenicity and tetragenicity are yet to be established. Meantime, the gas should be handled with proper care.

\section{RERERENCES}

1. Arsenic and arsenic compounds. Overall evaluation of carcinogenicity: an updating of IARC monographs volumes 1 to 42. In: IARC Monographs on the Evaluation of Carcinogenic Risks to Humans. Suppl 7. Lyon: International Agency for Research on Cancer; 1987. p. 100-6.

2. Naus A. Olfactory threshold of some industrial substances. Pracov Lek 1982;34:217-8

3. IPCS International Programme on Chemical Safety. Concise International Chemical Assessment Document. No. 47. Arsine: Human Health Aspects. Geneva: World Health Organization; 2002.

4. De Palma AE. Arsine intoxication in a chemical plant. Report of three cases. J Occup Med 1969;11(11):582-7.
5. Pinto SS. Arsine poisoning: evaluation of the acute phase. Case report. J Occup Med 1976;18(9):633-5.

6. Clay JE, Dale I, Cross JD. Arsenic absorption in steel bronze workers. J Soc Occup Med 1977;27(3):102-4.

7. Risk M, Fuortes L. Chronic arsenicalism suspected from arsine exposure: A case report and literature review. Vet Hum Toxicol 1991;33(6):590-5.

8. Williams PL, Spain WH, Rubenstein M. Suspected arsine poisoning during the restoration of a large cyclorama painting. Am Ind Hyg Assoc J 1981;42(12):11-3.

9. Mora V, Pairon JC, Garnier R, Laureillard J, Lionnet F, Hoguet L, et al. Acute arsine poisoning in a ferrous metal foundry. A report of two cases. Arch Med Prof 1992;53(3):167-73 [in French].

10. Romeo L, Apostoli P, Kovacic M, Martini S, Brugnone F. Acute arsine intoxication as a consequence of metal burnishing operations. Am J Ind Med 1997;32:211-6.

11. Braszczynska Z, Linscheid D, Osinska R, Klopotowski J. Evaluation of the exposure to arsenic compounds in zinc smeltres. Med Pr 1983;34(5-6):413-7 [in Polish].

12. Cheng CN, Focht DD. Production of arsine and methylarsines in soil and in culture. Appl Environ Mirobiol 1979;38(3):494-8.

13. Kleinfeld MJ. Arsine poisoning. J Occup Med 1980;22 (12):820-1.

14. Wald PH, Becker CE. Toxic gases used in the microelectronics industry. Occup Med 1986;1(1):105-17.

15. Scott N, Carter DE, Fernando Q. Reaction of gallium arsenide with concentrated acids: formation of arsine. Am Ind Hyg Assoc J 1989;50(7):379-81.

16. Sheehy JW, Jones JH. Assessment of arsenic exposures and controls in gallium arsenide production. Am Ind Hyg Assoc J 1993;54(2):61-9. 
17. LaDou J. Potential occupational health hazards in the microelectronics industry. Scan J Work Environ Health 1983; 9(1):42-6.

18. Jones W, Gamble J. Epidemiological-environmental study of lead acid battery workers. Environ Res 1984;35(1):1-10.

19. Bentley R, Chasteen T. Microbial methylation of metalloids: Arsenic, antimony, and bismuth. Microbiol Mol Biol Rev 2002;66(2):250-71.

20. Richardson BA. Cot mattress biodeterioration and SIDS. Lancet 1990;335:670.

21. Richardson BA. Sudden infant death syndrome: A possible primary cause. J Forensic Sci Soc 1994;34:199-204.

22. Sprott J. Arsenic in sheepskins a major cause of cot death [cited 2005 Dec 21]. Available from: http://www.pnc.com.au/ cafmr/sprott.

23. Klimecki WT, Carter DE. Arsine toxicity: Chemical and mechanistic implications. Invited Review. J Toxicol Environ Health 1995;46:399-409.

24. ACGIH. Documentation of threshold limit values for Arsine. Cincinnati $(\mathrm{OH})$ : American Conference of Governmental Industrial Hygienists; 2001.

25. Rogge H, Fassbinder W, Martin H. Arsin (AsH $\left.H_{3}\right)$-Intoxikation: Hämolyse und Nierenversagen. Dtsch Med Wschr 1983;108:1720-5.

26. Gosselin B, Mathieu D, Desprez-Nolf M, Cosson A, Goudemand J, Haguenoer JM, et al. Acute arsenious hydride intoxication. Four cases. Nouv Press Med 1982;11(6):439-42 [in French].

27. Bogdanik T, editor. Clinical toxicology. Warszawa: Medical Publisher PZWL 1988. p. 293-4 [in Polish].

28. Hesdorffer CS, Milne FJ, Terblanche J, Meyers AM. Arsine gas poisoning: the importance of exchange transfusions in severe cases. Brit J Ind Med 1986;43: 353-5.

29. Stokinger HE. Arsine, $\mathrm{AsH}_{3^{3}}$ In: Clayton DG, Clayton FE, editors. Patty's Industrial Hygiene and Toxicology. 3rd ed. Vol. IIA. Toxicology. New York: Wiley Interscience, John Wiley and Sons; 1981. p.1528-30.

30. Togaybayev AA, Lapin VI, Sheynin GD, Sultanbayev BK, Shel FG. Intensive therapy of hydrogen arsenious poisoning. Anestez Reanimatology 1984;4:46-7.

31. Blair PC, Thompson MB, Bechtold M, Wilson RE, Moorman MP, Fowler BA. Evidence for oxidative damage to red blood cell in mice induced by arsine gas. Toxicology 1990;63(1):25-34.

32. Blair PC, Thompson MB, Morrissey RE, Moorman MP, Sloane RA, Fowler BA. Comparative toxicity of arsine gas in B6C3F1 mice, Fischer 344 rats, and Syrian golden hamsters: system organ studies and comparison of clinical indices of exposure. Fundam Appl Toxicol 1990;14(4):776-87.

33. Bulmer FMR, Rothwell HE. Chronic arsine poisoning among workers employed in the cyanide extraction of gold: A report of fourteen cases. J Ind Hyg Toxicol. 1940;22:111-24.
34. Hong HL, Fowler BA, Boorman GA. Hematopoietic effects in mice exposed to arsine gas. Toxicol Appl Pharmacol 1989;97(1):173-82.

35. Morrissey RE, Fowler BA, Harris MW, Moorman MP, Jameson $\mathrm{CW}$, Schwetz BA. Arsine: absence of developmental toxicity in rats and mice. Fund Appl Toxicol 1990;15: 350-6.

36. Hatlelid KM, Brailsford C, Carter DE. An in vitro model for arsine toxicity using isolated real blood cells. Fund Appl Toxicol 1995;25:302-6.

37. Hatlelid KM, Carter DE. Reactive oxygen species do not cause arsine-induced hemoglobin damage. J Toxicol Environ Health 1997;50:463-74.

38. Winski SL, Barber DS, Rael LT, Carter DE. Sequence of toxic events in arsine-induced hemolysis in vitro: Implications for the mechanism of toxicity in human erythrocytes. Fund Appl Toxicol 1997;38:123-8.

39. Hatlelid KM, Brailsford C, Carter DE. Reactions of arsine with thaemoglobin. J Toxicol Environ Health 1996;47:145-57.

40. Levinsky WJ, Smalley RV, Hillyer PN, Shindler RL. Arsine hemolysis. Arch Environ Health 1970;20:436-40.

41. Ayala-Fierro F, Baldwin AL, Wilson LM, Valeski JE, Carter DE. Structural alterations in the rat kidney after acute arsine exposure. Lab Invest 2000;80(1):87-97.

42. Apostoli P, Alessio L, Romeo L, Buchet JP, Leone R. Metabolism of arsenic after acute occupational arsine intoxication. $\mathrm{J}$ Toxicol Environ Health 1997;52(4):331-42.

43. Parish GG, Glass R, Kimbrough R. Acute arsine poisoning in two workers cleaning a clogged drain. Arch Environ Health 1979;34 (4):224-7.

44. Aitio A, Hakala E, Pyy L. Arsenic. In: Anon, editor. Biological Monitoring of Chemical Exposure in the Workplace. Vol. 2. Geneva: World Health Organization; 1996. p. 18-34.

45. Intersectoral Committee for MAC and MAI Values. Hazardous Agents in Occupational Environment-Higienic Standards. Warszawa; Central Institute for Labour Protection - National Research Institute; 2005.

46. Landrigan PJ, Costello RJ, Stringer WT. Occupational exposure to arsine; an epidemiologic reappraisal of current standards. Scan J Work Environ Health 1982;8(3):169-77.

47. ACGIH. Arsenic and soluble inorganic compounds. Documentation of recommended BEI. Cincinnati $(\mathrm{OH})$ : American Conference of Governmental Industrial Hygienists; 2001.

48. Vahter ME. Arsenic. In: Clarkson TW, Friberg L, Nordberg GF, Sager PR, editors. Biological Monitoring of Toxic Metals. New York (NY): Plenum Press; 1988. p. 303-21.

49. DFG. Sulfuric acid. In: Greim H, editor. Occupational Toxicants. Critical Data Evaluation for MAK Values and Classification of Carcinogens. Vol 15. Weinheim: Deutsche Forschungsgemeinschaft, Wiley-VCH; 2001. 
50. ACGIH. Threshold Limit Values for Chemical Substances and Physical Agents and Biological Exposure Indices. Cincinnati $(\mathrm{OH})$ : American Conference of Governmental Industrial Hygienists; 2005.
51. RTECS (Registry of Toxic Effects of Chemical Substances) from MDL Information System, USA, ChemBank on SilverPlatter, December 2005. 